$$
\text { スポーツに护忏っニニタス性」 }
$$

多 本 直 文 (東京都立大学)

\title{
“COMMUNITAS” IN SPORTS
}

\author{
Naof umi Masumoto \\ Tokyo Metropolitan University \\ Yakumo,Meguro, T okyo (152)
}

\begin{abstract}
The purpose of this study is to clarify the specific behaviors of sport groups by means of the concept, "communitas" which is offered by V, Turner. This analysis takes the semioticstructual method which differs from the structual-functional one. And the ritual process in sport is interpreted in the light of the cultural-anthropology. The procedure of this study, firstly, makes an overview of the concept, "communitas", which appears in three dimensions of culture ; "liminality", "outsiderhood", and "structual inferiority", then proceeds to the relation with the rite of passage. Secondly, in view of the interaction of members, "communitas" can be demonstrated with "rhizome type" model which takes the form of the multidimensional network system. On the contrary, "community" is characterized by "tree typ" model. According to these procedure, this analysis proceeds to the examination of "communitas" and the ritual traits in sport groups.

The results are as follows ;

1 ) It is necessary for the analysis of sport groups characterized by "communitas" to take supplementary approach with the team-work theory which has been developed for the social structual system.

2) The specific behaviors in sports, e.g. the encouraging shout and cry "GANBA !", or mass running exercises in formation, could be clarified as "rites of passage" or "transition rites" in broad sense.

3) This shout "GANBA !" is a password for performing audiences to take part in the sport situation sympathetically. At the same time, the shout is also a prayer for athletes to enter into the movement landscape or background of ordinary sports.
\end{abstract}


緒言

我国の競技スポーツに扣いては，練習時や試合 時に普段の社会生活一日常性一に比べ，かなり特 有な集団行動が見受けられる。例えば，隊列を組 んで号令を掛けながら全員が一斉に行らランニン グや準備運動, 自分自身に対する鼓舞やチームメ イトへの叱咤激励的な「ファイト!」「ガンバ!」 などの掛け声，円陣を組んでのエールやミーティ ング, 補欠プレーヤーが球拾いをしながら引切無 しに発する雄叫，それに「同じ釜の飯を食う」と いう合宿システムなどである。これらの現象は集 団で行らスポーツに顕著であるが，個人種目でも チームとして競技集団が形成されるならば，必ず といっていい程，よく見受けられるるのである。

このよらな集団行動は, 普段の日常的な行動と 比べるならば，特異なものであり，記号論的には 「有徵」「徵つき」住1) といえよう。また，それ らの行動は何がしかの儀式性を有しているとも考 えられる。このような有徵で儀礼的なスポーツ特 有のさまざまな行動を伴らスポーツ集団は，どの ように把握されるべきであろらか。一般的にいえ ば,このような行動はあたかもチーム・ワークの 良さを如実に示すものだとされよう。

学校の教科体育に招いては, 「学習指導要領」 により, 次の項目が運動やスポーツを通じて育成 される社会的な目標として揭げられている。すな わち，「だれとでも仲よくし」「協力，公正など の態度を育てる」(小学校 ${ }^{1)}$ ) 「運動に拈ける競 争や協同の経験を通して公正な態度を育て，進ん で規則を守り，互いに協力して責任を果たすなど の態度を育てる」(中学校 ${ }^{2)}$ )「各種の運動を合 理的に実践し，運動技能を高めるとともに，それ らの経験を通して, 公正, 協力, 責任などの態度 を育て…」(高等学校 $\left.{ }^{3}\right)$ )などの項目は, スポー ッ集団として競争と協同という社会関係の中で, 従来の集団論のパラダイムに立脚した「チーム・ ワーク」の良さを目標としているかのように思わ れる。つまり, 学校体育やスポーツ教育に拉いて は, 公正, 協力, 協調などの人間の社会性の育成 が教育目標の一つとして揭げられ，その期待も大 であることが窥い知れる。
このような考え方には, 前述したスポーツ集団 特有のさまざまな儀礼的行動は, あたかもチーム・ ワークの良さの現れであり，それは社会性の自動 的な育成に通ずるという図式が隠されている。ま たそこにはスポーツに対する過剩なる期待, 思 い入れという感もま妨れい。果して, 公正, 協力, 協調などの社会性の育成一ある意味では全 体社会に必要とされ，望ましいとされる秩序であ り規範であるが一はスポーツに拈いて可能であろ らか。たとえ教育操作がそこに介在する必要性が 自覚されていたとしてでもである。

従来のスポーツの集団論的研究が既存の集団論 の援用一構造一機能連関的アプローチーであり， それなりの成果をあげてきたことは周知の通りで ある永2)。しかし，そこにはスポーツ集団の儀礼 性や象徵的行動などが看過されていたとはいえな いであろらか。スポーツ行動の深層構造は, この ような儀礼性や象徵的側面から問ら必要があり, スポーツ集団の分析は，この側面と構造一機能連 関的分析の側面との相補的関係でもって理解され るべきである。なぜならば，スポーツ集団には実 社会と類似した役割や地位などの秩序立てられた 構造一機能的関係だけでなく，スポーツ独自の文 化的で象徵的な関係も具有しているはずであるか らである。つまり, 試合中では学年や年齢などの 序列関係が棚上げされるし, 役割りの肩代わり （ポシシションチェンジなど）歹時々起こる。をれ 以上にさまざまな儀式的行動が見られるする。

そこで，本論考では，スポーッ集団特有のさま ざまな集団行動に着目し，V．ターナーのいら広 義の感性的共同体をさす「コミュニタス」という 概念装置 注3) を導入することによって, 構造一機 能連関的な集団論とは別の視点からスポーツ集団 を分析することを目的としている。考察の対象と するスポーツ集団はプロフェッショナルな集団を 除き，小・中・高・大学あたりの競技スポーツ集 団を念頭に置く。方法論的にいえば, スポーツに おけけ「コミュニタス」といら集団的特性は, 文 化人類学的アプローチ, 文化記号論的アプローチ に基づいて示されることになる。また，スポーツ の儀式性は文化人類学的知見から解釈されること になる。さらに，スポーツ集団の人間関係をモデ 
ル的に示すために, 最近注目されているポスト構

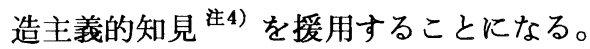

このよらなスポーッ集団の特性を深層構造と表 層構造の相方から相補的に検討することを踏まえ た上で，スポーツ教育に括ける社会性の育成とい 万目標は見直される必要があろら。本論考はその ための準備的性格をも有している。

\section{本論 \\ 1.コミュニタスについて}

さて,「ュミュニタス communitas」とはV． ターナーの用語であり, 従来の社会学で重要な 位置を占める「社会構造」とは対照的な概念装置 としての性格を有している。スポーツにおける 「コミュニタス性」を分析する前に, この語の語 源や関連する語を概観し, 次いでこの用語の検討 へと進みたい。

\section{1)「コミュニタス」への語源的・用語的 アプローチ}

「ュミュニタス」とはラテン語のcommunitasで あり，これはcommunis (=common) の変化し たものと考えられる注5)。このcommunisから派 生したものとしてcommunityがある。このコミュ ニティとは, 共同社会・共同生活体・ゲマインシャ フト・地域社会・共通の特徴をもつ集団というほ どの意味であるが，これは規範的で序列化され， 役割や地位の分化した「社会構造」であるとされ る。これは後述するように反構造としての「コミュ ニタス」とは対照的なものである。しかし，コミュ ニティの語源をcommunitasとする説もあり, 関 連性が大きいといえよう。「コミュニタス」に関 連する語でcommunisを語源とするるのとして， 他には「コミューンcommune」一共同生活を営 む集団，（共産主義的）共同生活体，ヒッピーの 生活共同体などー「ュミュニオンcommunion」 一共有, 仲間, 霊的交渉一「コミュニケーション communication 」や「コモン・センスcommon sense」一センスス・コムニス（sensus communis）
としての共通感覚 ${ }^{4)}$ 一が挙げられる。これらの語 群から「コミュニタス」の広い意味での感性の共 同体としての人間関係様態を窥い知ることができ よう。また，コミュニティの原初形態として語源 的な「コミュニタス」はその純粋な集団性, 混沈 性を浮き彫りにするといえよう。

2) V.ターナーの「コミュニタス」

V.ターナー5）6）によれば,「コミュニタス」 といら社会関係は, 宗教, 文学, 演劇, 美術の根 幹を形づくり, 法, 倫理, 親族関係, 経済にも深 い影響を有しているとされる。これは部族社会の 通過儀礼，千年王国運動，僧院，対抗文化などの 場面に現れるが，日常性格のなかでも遭遇しらる ものであるとされる。ここで重要な点は, 社会学 で広く研究されている「社会構造」とは極めて対 照的なるのであるという点である。この両者の対

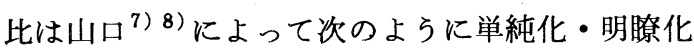
されている。「コミュニタス」とは広義の感性の 共同体, 情緒的共同体であり, 宗教, 芸術, 文化, 演劇などの精神の文化にみられるもので，信頼， 人間的暖かさと自由を得る反文化的仕掛け，カウ ンター・カルチャーなどのインフォーマルな行動 形態である。他方, 「社会構造」は規範の共同体 としての「コミュニティ」であり, 法, 倫理, 親 族, 経済などの規範の文化にみられる。

ターナーによれば, この「コミュニタス」を象 徵的に表現する儀礼やシンボルや信仰は，「境界 性 liminality」「部外者性 outsiderhood」「構 造的劣性 structual inferiority」といら三つの文 化上の側面に現れるとされる。

「境界性」とは, 通過儀礼（移行儀礼）に括け る分離一周縁一再統合といら明確に区切られた三 段階の中の中間段階, つまりどっちつかずの暧昧 な状態をさす。この三段階プロセスの分離の局面 では, 象徵的な分離儀礼でもって社会構造上の地 位や固定した文化条件から離脱していくことにな る。通過者は象徽的な死をもって不可視の存在と なり, 社会構造からハミ出した周縁的存在となる。 移行が完了すると統合の儀礼でもって再び社会構 造のなかに統合される。「コミュニタス」はこの 中間の境界状態に生ずるとされる。構造上の地位 
を示寸徵は剩ぎ取られ，どっちつかずの両義的存 在となる。平等性や仲間意識を規範とする関係の レベルから，自発的かつ実存的な「コミュニタス」 のレベルまで，その状態はさまざまであるとされ る。

「部外者性」とは, 社会構造で認知された地位 や役割に基づくのではなく, その外部に生ずる行 為や人間関係をさすとされる。そこには, 常に社 会構造からはずれている場合と, 一時的に自ら進 んではずれる場合の二つが考えられている。この ような「部外者性」の例として, ターナーは, シャー マン, 司祭, 占い師, ヒッピー, 浮浪者, ジプシー などをあげている。この「部外者性」と「境界性」 とは，どっちつかずの宙吊りの状態という共通性 を有して拈り，そこに「コミュニタス」が生ずる といらわけである。

「構造的劣性」とは, 社会の人間関係には構造 的にみて強弱の関係が存在し, それが二項対立を 示すことになるわけであるが，その構造的に劣位 な集団が「コミュニタス」を形成するとされる。 例として, 父系社会に対する母系社会, 征服民に 対する被征服民（土着民）などがあげられて扣り， その劣位な集団は柔軟で情緒的で神秘的な補完関 係を示すとされる。

山口 ${ }^{8)}$ はこのような三つの側面を有した「ュミュ ニタス」の好例として，日本の時代劇にみられる 「長屋」のイメージをあげている。この「長屋」 に颃いては, 出自や階級的起源は解消され, 住人 同志の感性的・情緒的連帯が特徵とされる。さら に山口は「長屋」には「過度性といら時間的表現, 他椞著性 (異人性) といら社会空間的表現, 貧困 といら構造的表現がすべて顕在化し，それらの表 現を通して情緒共同体といら象徵的レヴェルが捉 えられる」といら。この例はまさに正鵠を得て いるといえよう。現代では, 竹の子族, ロックン ローラー族, 暴走族などもこの「コミュニタス」 の例と考兄らるが，スポーツ集団にもこの性向 が窥われる。

3)「コミュニタス」と通過儀礼

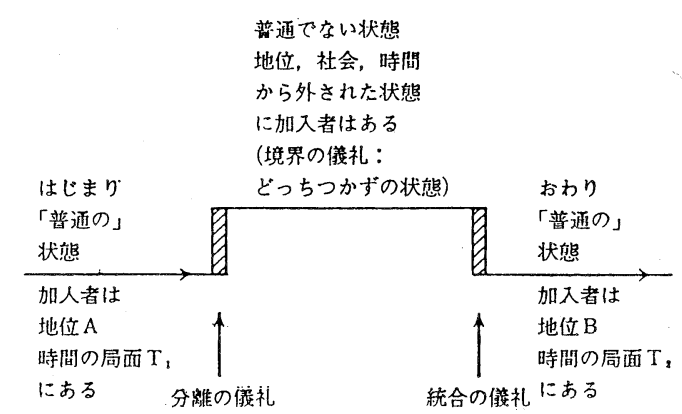

図 1. 通過儀礼のモデル

（E.リーチ，文化とコミュニケーション，紀伊国屋書店, 1981）

E.リーチ9) は図 1 のように通過儀礼をモデル 化している。そこでは, 分離儀礼, 境界儀礼, 統 合儀礼の三つの局面がみられるとされる。青木 ${ }^{10)}$ はこのリーチのモデルに従い, 通過儀礼は全体 として, 象徵的な死, 儀礼的な隔離の期間, 象徵 的再生といら三つのレベルによって構成されると した。この三段階の中間状態である社会上無時間 的な休止の期間に「コミュニタス」が形成される といってよい。それは俗一聖一俗, あるいは, 日 常一非日常一日常といら図式でも示されらるなら ば,「コミュニタス」は聖 (非日常的秩序)を有 するともいえよう。

中村 ${ }^{11)}$ は, 通過儀礼を人生の節目に打いて 「象徽的な死と再生を通して脱皮していく働きで ある」（傍点著者）と規定し, 現代社会では加入 儀礼としての成人式が形骸化して本来の力を失い, そのためにく永遠の少年>症候群やャクザッぽい く暴走族〉の出現をみることになると指摘してい る。特に暴走族は加入儀礼が本来もつべき日常性 から隔離と特権的な秘儀への参加を期せずして体 現しているとし, 暴走といら非日常的な集団行動 は,ターナーのいら「コミュニタス」という概念 にそっくり当てはまるという。

暴走族の集団的特性とスポーツ集団の特性には 類似した点が多くみられる。両者とも自発的, 平 等的で感性の共同体, 情緒的共同体の性格を有し ているし, 両集団特有の加入儀礼, 脱退儀礼, 地 位や役割の移行儀礼を形成し，それを伝え守って もいる。しかも, 地位や役割の分化が進行するに つれて，両集団とも「コミュニタス性」を衰失し 
ながらも統合一分裂一再生などのダイナミックな 展開を示し，自己集団の組織化を進めるのである。

\section{4)「コミュニタス」の組織モデル}

集団の組織化, 体系化に関して, 最近二つの対 照的なモデルを示す方法がよく行われている。そ れは，ツリー（樹木）型とリゾーム（根宔）型の 二つのモデルであり，中村 ${ }^{12)}$ は「とくに後者の 在り様が現代文化のさまざまな領域…の問題に新 しいモデルを提供している」と指摘している。こ のモデルは, 人間関係に限らず, 諸々の項目の相 互関連性を示す際に，それらの多様性を示すため に用いられることが多い。このツリー型とリゾー ム型といら概念は, ポスト構造主義の思想家とさ れるG.ドゥルーズとF.ガタリによって示された ものであるが，アレクサンダーもツリー型とセミ・ ラティス (半束) 型という類似した概念を示して いる。
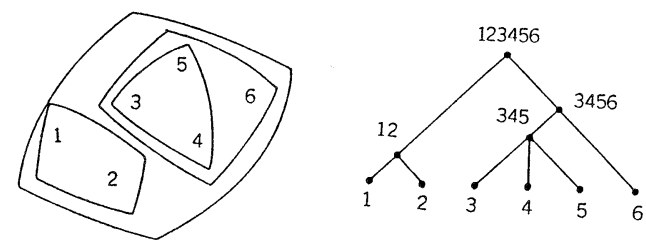

図 2. 樹状非交又図式 (ッリー型)

（市川浩〈身〉の構造 青土社，1984，図 3，4 6同様）
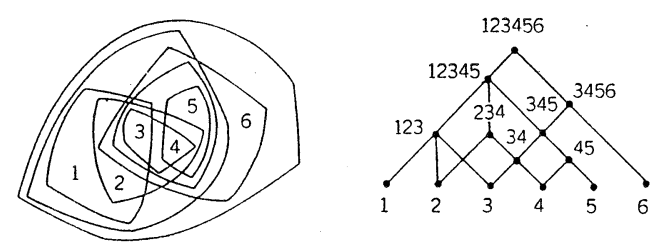

図 3. 網状交又図式（セミ・ラティス型）

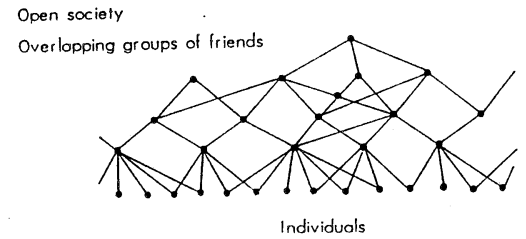

図 4. 多次元ネットワーク（リソーム型） |j川 ${ }^{13 ）}$ はこの両者のモデルを「く身>の構造 とその生成モデル」として図2．3．49よ5に 「樹状非交叉図式（ツリ一）」「絧状交叉図式 (七ミ・ラティス)」「多次元網状図式（リゾー ム)」の三つのモデルで示している。

この三つのモデルの関係は中村と市川によると 次の様に整理できよう。これらのモデルは，人間 の神経システムや運動システムのような自己組織 化や自己体系化，あるいはりビング・システムな どの原理として示されたものである。ツリ一型は， 軍隊や官僚組織などのように, 階層構造を最優先 させる組織であり，固定式・閉鎖的な関係である とされる。セミ・ラティス型はツリ一型に横断的 連絡の組み込まれた中間的なものであり,ツリー 型の交叉型ともいえ，クラスの重複が多義性をも らたすシステムとされる。また，ツリ一型は人工 的システム, セミ・ラティス型は自然発生的なシ ステムであるともいわれている。さらにこの重複 性, 横断的連絡が進んだシステムが，多次元ネッ トワーク型（リゾーム型）のシステムであり，最 近の文化理論や情報理論に括いて注目されている ものである。このリゾーム型は，どの任意の一点 でも他の任意の一点と統合でき，また，どの一点 に执いても分節されらる多様体であり，いかなる 構造モデルにも生成モデルにも属さないとされる。 「それは諸状態の交通のみによって規定される脱 中心化システムであり, あらゆる種類の旌成であ

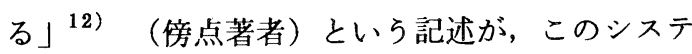
ムの多様性を示唆する。

「コミュニタス」をこの三つのモデルと対応さ せるならば，第三のリゾーム型モデルが対応する。 一方, 社会構造としての「コミュニティ」は第一 のッリー型に対応し, 両者の中間的な集団組織が セミ・ラティス型として位置づけられよう。模式 的に示すならば, 競争社会・学歴社会のように役 割や地位が分化し成層化された序列化社会, 機能 重視の秩序づけられた実社会は, ツリ一型の社会 構造を特徵とする。一方, さまざまな移行儀礼や 加入儀礼, 通過儀礼などを具有し, 集団成員の紏 を確認するための日々の特殊な儀式的行為を伴う 「コミュニタス」としてのスポーツ集団は, 自由, 平等, 自発的, 無礼講的な集団であり, 地位や役 
割は実社会汪ど分化して括らず，その成層化もさ ほど固定的ではない。また，感性的でシンボル的 な人間関係をその主たる集団的特徵とするため, 成員間の繋りは高く，その人間関係はまさにリゾー ム型といえよう。これは極端な図式であるが，ス ポーツ集団は実際にはこの両者の特徵を合わせ持 つと考えるべきであろら。しかし，人間的な絆や 紐帯の強固さの点を考えるならば, 集団として凝 集性が高いのは「コミュニタス」のよらなリゾー ム型のシステムであるといえよう。

2、スポーツにおける「ュミュニタス性」

以上みてきた「コミュニタス」の概念装置を用 いて，現代スポーツの集団的特性を明らかにして いきたい。ここでは，先ず従来のチーム・ワーク 論を概観し, 本研究との関係や関連した研究に言 及する。次いで, ターナーの「ュミュニタス」の 三側面とスポーツの対応を検討し，更に，スポー ツの儀礼性や象徵性の検討へと進みたい。

\section{1 ) 関連研究}

学校体育で期待される社会性の育成は, チーム・ ワークの良さをその形成（達成）過程の証しとし て考えられることが多いといえよう。しかし，そ のチーム・ワーク論はツリ一型の社会構造に対応 した観点から提示されているものである。ところ

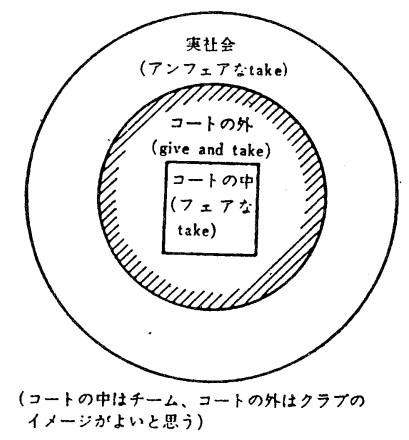

図 5. スポーツ空間のモテル

（荒井貞光「チームワークを生み出すための集団運営の技術」 体協監修「コーチのためのスポーツ人間学」大修館書店 1981)
で, 荒井 14）はチーム・ワーク論を展開する際に ，図5のような「コートの中」「コートの外」と いらスポーツの空間モデルを示し，チーム・ワー クを高めるためには「コートの外」としてのクラ ブワークが重要であるとした。ここには, スポー ツの境界性が窺い知れるが，それ以上に構造一機 能的意味連関からの主張をその特徴としている。

さて,チーム・ワークとは「成員がそれぞれの 地位, 役割に応じて責任を果たし、コミュニケー ション communicationを円滑に行ない，相互に 信頼しあっているまとまりのある状態」「…グルー プのメンバーが共同の目的に向って精神的・技術 的に協力しあって行動する相互作用」15）である とされる。前述した「コミュニタス」と「コミュ ニティ」との対比に基づくならば，このチーム・ ワークの定義が該当する集団は, ツリ一型の「コ ミュニティ」であるとみなすことができよう。そ れは, チーム・ワーク論が既存の集団論の援用で あり，スポーツ集団のオールタナティブな側面へ の視点（両義性への視点）を欠落させていること に起因している。荒井のスポーツの空間モデルは, スポーツ集団の「コミュニタス性」を示唆してい ると考えられるが，その「コミュニタス性」とい らメンバー間の相互作用の様態こそ分析される必 要があった。つまり, 既存のチーム・ワークの神 話は，既存の実社会から望まれる集団様態をもと に形成されたものであり，多次元ネットワーク的 モデルをその特徵とするスポーツの集団論におけ るチーム・ワーク論は, 残念ながら未着手の領域 であるといってよかろら。本来的には, スポーッ 集団のチーム・ワーク論はこの両者によって相補 的に展開される必要があろら。

\section{2) スポーツにおける「コミュニタス」}

形成のメカニズム

図6は「ラインを引く」という授業過程の一つ の事象を例にとり，それを記号過程として展開す る際の問題領域を示したものである注6)。「ひろ 場にラインを引く」といら象徵的事例は, 文化記 号論的概念装置を導入することによって，次のよ うな記号化プロセスでもって劇的に示される。こ のラインはコート空間を「分節」し，他のスポー 


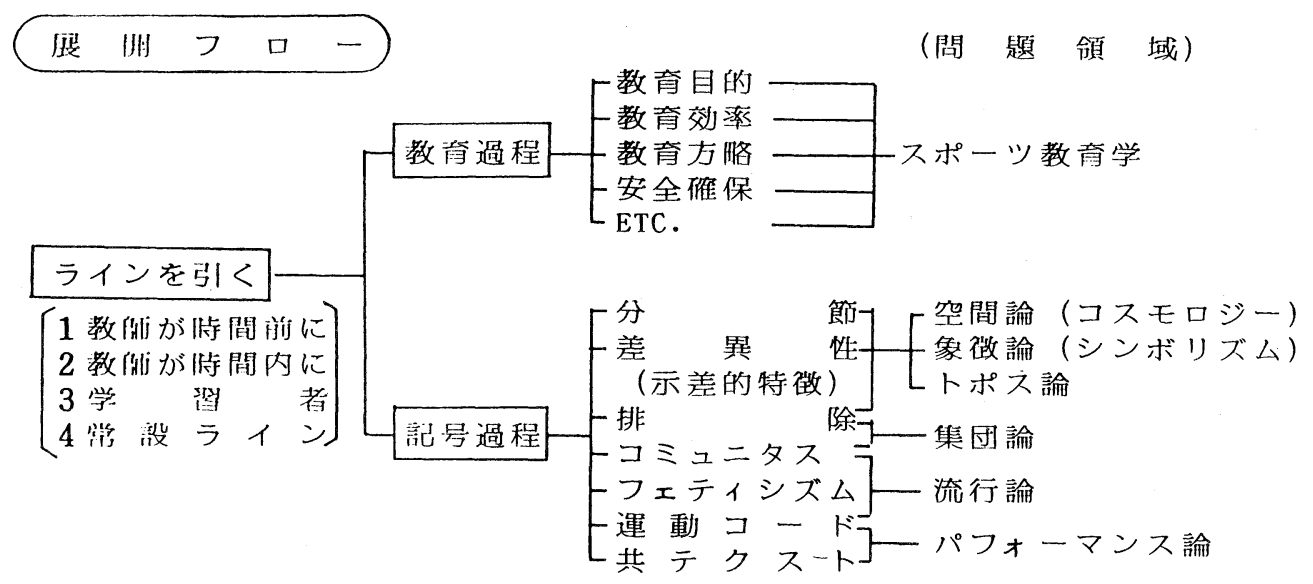

図 6.「コミュニタス」の記号過程

ツのコートや空間との「差異性」を示すことによっ て，他者や他の集団，あるいは他の空間を「排除」 する（逆にいえば，自分達のアイデンティティを 確認する）ことになる。そのため, 特定集団専用 のコート空間が醸成され，「運動コード」注7）に 基づいた特定のスポーツ種目の実施が規定されて しまう。それがひいてはュート空間の「フェティ シズム」への道を秘めているといら構図である。

テニスを例にとれば，テニスュートのラインは 他のコートを区別，排除し，そこではテニスのみ のプレーが許される。それはテニスの集団以外の 人間を排除してしまうことになる。さらに，その テニスコートへの出入りやそこのクラブのメンバー になることがステイタスなどの記号となり，その 記号を所有しようとする願望はフェティシズム

（物神がそこに存在するかのように崇める）への 道である。このようなプロセスにみられるスポー ツの特定集団の形成と他のスポーツ集団の排除こ そが「コミュニタス」が形成されるメカニズムの 第一歩なのである。

ここで杉本 16) のコミュニティ・スポーツ論が 示唆に豊む。杉本はスポーツで作られる連帯意識 は, 排他的状況を生み, スポーツ集団の地域との 乘離を生んだこと，スポーッといら非日常での連 帯が日常での連帯へと転移する可能性が薄く, 逆 に現実の問題を隠蔽する可能性を内包していると いう批判的見解を提示している。このスポーツ集
団の排他性こそ「コミュニタス」の特徽であり, そこに护ける成員間の共生一連帯や同調, 共感一 はそこに打いてのみ意味を有し，通用するのであ る。その連帯, 䊼のためには, 実社会 (全体社会) にとって反規範的なことが活用される場合が多い。 それがスポーツ集団の周縁的特徵であり，反一構 造という性格を有する「コミュニタス」の特徴を 形つくっている。

3) スポーツに拈ける「コミュニタス」の 三側面

ターナーの「コミュニタス」は「境界性」「部 外者性」「構造的劣性」といら三つの文化の側面 に現れるとされ，山口はその典型として「長屋」 のイメージを提示したことは前述の通りである。 ここでは, 青木とリーチの通過儀礼に打ける三局 面（図 1) とターナーの「コミュニタス」の三側 面とを関係づけてスポーッの儀礼性にアプローチ してみたい。

スポーツに括ける通過儀礼, 加入儀礼としての 儀式性は, 近年の伝統的な通過儀礼の形能化と相 俟って重要な位置を占めてきている。度胸だめし 的行動はスポーツに特有の要件である。挑戦的行 動は脱中心化一再統合といらプロセスを含む。例 えば，スキーで不整地（コブ）の急斜面を直滑降 で滑れなければ，スキー学校の指導者にはなれな いとか，ゲレンデ・シュプルングは一人前のスキー 
ヤーとしてのエンブレムともみなせよう。少年野 球では硬球を使用できるとこが一人前の野球プレー ヤーの証しでもある。日々のサイクルにもスポー ツの儀礼性は, その分離一境界一統合のプロセス を象徵的に顕わにする。スポーツウェアに着替え, 円陣を組んで開始のエールを叫び，集団で隊列を 組んで掛け声を出しながらジョギングや準備運動 は，日常性から聖なるスポーツ世界へと移行する 儀礼なのである。練習終了時の円陣を組んでのェー ル, グラウンドやュートから出る際の一礼, 聖水 としてのシャワーは, 日常の社会構造へと再統合 される移行の儀礼でもある。このように, 長期的 にも短期的にも, 現在の自己を新たなる自己へと 改革し, 再統合されていくといらプロセスをスポー ツ集団の「コミュニタス性」は提供しているとい えよう。

第二の側面の「部外者性」に関していえば，ス ポーツ集団の人間関係と実社会の地位や役割とは 全く別の様相を呈することが多い。それはスポー ツ集団の成員が自ら進んで一時的に社会構造から 離脱することに起因する。つまり, 実社会とは別 の宙吊りの状態に入っていき，そのどっちつかず の状態に入っている徵としてさまざまな象徵的儀 礼が行われ，無礼講的振舞いが許されることにな る。後述する「ガンバ!」もこの段階の義礼のた めの呪文なのである。

構造的にみれば, 全体社会に比ベスポーツ集団 は劣位にあるといってよい。つまり, 現実の社会 はツリ一型の秩序化され序列化, 成層化された社 会であり, 経済や政治的脈絡に基づいた地位や役 割の支配する社会である。そのため，スポーツの 「コミュニタス性」は実社会との相補的な関係を その利点としているのかもしれない。しかし、ス ポーツ集団には常に即座に実社会の論理や秩序が 導入される。用具や技術, 記録や賞金額などの面 にスポーツ集団成員間のハイアラーキーが形成さ れ,「コミュニタス」は崩壊せざるを得ない運命 にある。

4) スポーツに拈ける「コミュニタス」と 「トポス」

上述のような「コミュニタス」に扰ける儀礼性
を伴らスポーツ集団は，中村 17）のいら「トポス (場, 場所)」を形成しているとも考えられる。 中村によれば, この「トポス」といら概念は「象 徵的なものとしての場所」「身体的なものとして の場所」「問題の具体的な考察と議論にかかわる ものとしての場所」「根拠的なものとしての場所」 という四つの側面をるつとされる。

第一の象徵的な側面として，スポーツの空間性 は世俗的な空間とは区別され，スポーッ独自の論 理から醸成される濃密な意味之有意味な方向を持っ ている。第二の身体的側面では，スポーッ独自の 運動形態，運動様式によって，その活動する身体 を通して分節化された空間性を有する場が形成さ れる。それは運動の風景や背景を決定するのであ り，その空間性はく身でもって知っている>ので ある。第三の側面では，スポーッ集団の成員が人 生のある節々に, 自己の生を問い, 自己の可能性 をつきつめる場としてスポーツの世界も位置づく ことになろう。第四の根拠的な場は, 主語的なる のではなく述語的なものにあるとされる。つまり， 主語とは物のことであり, 述語的とは存在の状態 概念のことをさす。スポーツに拈ける「コミュニ タス」といら関係的状態は, 存在根拠を求める場 としての性格を有するといえよう。

5 ）「ガンバ!!」の儀礼性と「コミュニタス」 スポーツ場面に拈けるスポーツ集団特有の諸行 動を「通過儀礼」とみなした研究として, 杉本 ${ }^{18)}$ と阿部 19) のものがある。杉本は, 皆が号令を 掛けて行ら集団準備運動を日常性から非日常性へ の一種の通過儀礼としての「記号的意味」を持つ とした。阿部はバドミントン的世界に打ける叫び や応援の様態は「いけない撲殺し」「いたらない 私殺し」を行らことにらって, チームの仲間同志 の紏を強化するための通過儀礼であるという。

このように「コミュニタス」という特殊な感性 的・情緒的共同体の紐帯を確認し, 確固たるるの にするための集団儀礼として，スポーッ集団の号 令や「ガンバ!」等の掛け声は意味をもっと考兄 ることができよう。それは特に「演ずる観客」と しての応援団やベンチのメンバーには欠くことの できない特殊性であり, それらの儀式性によって, 
仲間や競争相手といら他者を介在させた，自己中 心化一脱中心化一再中心化といらプロセスに参画 することが可能になる。その掛け声は, 集団とし ての高揚状態に入っていくために発せられるので あり，その高揚状態を醸成し，さらに高揚した気 分を生み出す行為なのである。また，プレーヤー 自身が発する，あるいはプレーヤー間で交わされ る鼓舞的な掛け声は, 試合時と練習時との運動の 風景や背景を共通なるのにせんとするマジカルな 呪文であると考えられる。それを「ガンバ！」を 例にとって検討してみよう。

「ガンバ!」は「ガンバレ！」「ガンバロー！」 の短縮形であるが，これは「我に張る」から転じ たものであり，我意を張り通す，つまり，自分の 考えを押し通そらとする気持ち，わがままという 意味が本来的である。それは, 自己主張, 自己中 心化の勧めといらほどの意味になろう。現在では 「どこまでも忍耐してつとめる」20) という意味 が強くなっている。しかし，スポーツの場に拈け る「ガンバ!」にはその忍耐して努力する対象は 明示されないし，その必要もない。記号論的には， 具体的指示対象が不在であっても, それが特有の 意味を持つことになる。つまり，応援団や補欠の プレーヤーにとって,「ュミュニタス」としての スポーッ集団への参画の合い言葉（パスワード） としての意味を有するわけであるから，その掛け 声は, 「ファイト！」「シマッテイコウ!」「オッ ス!」「ウォーッ!」など何でも良いことになる。 ここには, 本来的には自己主張的意味を有する 「ガンバ！」が自己を殺し，集団に同調しなけれ ばならない図式が見受けられる。一方, プレーヤー の発する対自己的な「ガンバ！」は，自分自身に 対する叱咤激励の面す有しているが，常日頃の練 習の中で発することにより，練習一試合の状況を 類似したものにする意図も含まれている。つまり， 身で知っている運動の風景や背景を想起し, 自己 の運動パフォーマンスを日常のものにしようとす る期待から発せられる面をも含んでいるのである。

以上のように，スポーツ場面に批る「ガンバ!」 は象徵的に「コミュニタス」を醸成し，その境界 性という宙吊りの状態に移行していくための合い 言葉，あるいはその集団に参入するためのパスワー
ドであり，呪文であるといえる。観る側や応援す る側にとっても，演ずる観客としての台詞なので ある。これはある種の共生として，シンボル的な 世界を創り出すことになり，市川 ${ }^{13)}$ の言葉を借 りるならば，「間身体的な社会的同調図式」がそ こにみられるといえる。この好例として, ニュー ジーランドの大学ラグビーチームのフィフティー ンによって試合前に演ぜられる「ウォー・クライ」 があげられよう。これは土着民の戦いや狩りの前 の儀式としての集団的舞踏を始源とするが，現在 では そこには集団（フィフティーン）の紐帯を 高め, 聖なる競技へと移行していくための象徵的 意味が残されているのである。つまり，「ュミュ ニタス」への祈りであるといえようか。

\section{結 語}

スポーツの集団的特徵は「コミュニタス」をそ の本分とし，「コミュニティ」という社会構造一 それがチーム・ワーク論であったーと相補的関係 を有するといえる。従来のスポーツ集団論で看過 されていた「コミュニタス性」は, 反一構造的な 特性を有するものであり, 実社会（全体社会）で 期待される行動とは逆の行動形態をとる場合もあ りらる。

学校体育やスポーツ教育に拈ける社会性の育成 は，ただ単にスポーツ集団を形成し，運動を与え ていくことで自動的に達成されるものではない。 当然のことながら，そこにはさまざまな教育的操 作や配慮 (方略) が介在する。しかし, その前提 としてスポーツの集団的特性は十全に踏まえられ なければならない。また，スポーッ集団で育まれ る連帯性一共生や感性的・社会的同調一は実社会 ヘキャリー・オーバーされるものかどらかの検討 も重要となろら。それが不十分なまま, 昨今のア マチュアリズへの期待や, スポーツマンの非道徳 的行為への避難など，あまりにスポーツに対する 過利なる期待が見受けられるように思われる。

本研究では，スポーツ集団に特有のさまざまな 行動に着目し，それを「コミュニタス」といら広 義の感性的共同体, 情緒的共同体を生み出すため 
の通過儀礼や移行儀礼として促えた。聖なる状態 としての境界の状態に参画するための呪文として， 「ガンバ！」といら掛け声のもつ特性をも検討し た。このスポーツ集団の「コミュニタス性」は多 次元ネットワークシステム（リゾーム型）として その組織的な特徴をもっていたし，それは絶対的 に固定的なものでなく, 流動的, 生成変化するも のとして考えられる。また，スポーツの集団的特 性! 社会構造的な「コミュニティ」と「コミュニ タス」との両義性をゆれ動くものであるといえよ ら。

スポーツの象徵論的課題は山積している。具体 的事例を極度に掘り下げ，そこに拈ける儀礼性と 象徵性，その現在にもつ有意義性など更に検討す る必要がある。次なる課題としたい。

（本研究は，スポーツ教育学会第 4 回大会（1984） の発表をもとにしている)

注

注 1 ）「有徵」「徵つき」とは記号論の用語であ り, 厸義では普通 (平均) からの逸脱を示す その逸脱の方向には正・負の両ベクトルがあ る。㹨義の「有徵」と「無徵」の例として manと womanを例にとってみよう。両者と も記号内容として「人間」といらこを含むが manの方は男性という指定は不要であり, 一方, womanは女性という指定を必要 とする。そのためにmanは性に関しては， 「無徵」であり, womanは「有徵」という ことになる ${ }^{21) 。}$

注 2 ) 体育社会学専門分科会編「体育とスポーツ 集団の社会学」（1974）がこの好例。その他 体育社会学の集団論を参照されたい。具体的 一例として, 今村浩明氏の集団論研究の視点 と課題に関する論文や荒井貞光氏のチーム・ ワーク論 14）をあげておく（体育社会学専門 分科会編「体育社会学研究 $3 」)$ ）。さらに従 来のレクリエーションの集団論やコミュニテ ィスポーツ論も同じ範疇に入るといえよう。

注 3 ) 「装置」とする主たる理由は, 単なる分析
道具 (conceptual tool) としてこの概念を用 いるだけではなく，大がかりな仕掛けや劇的 な展開を目指しているからである。つまり， 分析視角としての意味合いだけでなく, 舞台 装置のような景色, 背景の急転回のように分 析対象の大巾な見直しや様相の大転換を可能 にせんとしているからである。

注 4 ) ポスト構造主義とは, 記号論や構造主義が 静的（スタティック）な構造を扱うに留まる との批判を受け，デリダのく脱構築〉，ドゥ ルーズのくリゾーム>などの主張に見られる ような, 動的関係として社会を促えな打す現 代の思潮である。多次元ネットワークシステ ムはく多数多様体〉というキーコンセプトに 依拠しているし，それは，官僚制のツリ一型 組織と対照的なものである。浅田彰, 中沢新 一などの思想が代表的であるが，本稿では， 市川浩氏の「<身>の構造とその生成モデ ル13)」を参考にすること大である。

注 5 ) 研究社「新英和大辞典」第 5 版, 1980年に よる。ただし,Webstar's New World Dictionaryによれば, communityの語源として communitasがあげられているのが興味深 い。つまり, communitasはcommunisの 変化したものであると考えられよう。

注 6 ）この展開フローは日本体育学会第35回大会 (1984) で「スポーツの記号論（1）-『コ ート空間』の記号性」と題して発表したもの である。

注 7 ）運動コードとは，まずコードが文化記号論 的には慣習化された行動や生活のきまり，抒 きて，規則などをさすことと合せ，運動文化 に拈ける運動のしかた，特定の運動のきまり といら意味である。一定の運動文化が形態を なすための文化規則といってよい。

\section{引用・参考文献}

1) 文部省「小学校学習指導要領」 1977, pp.91 $-97$

2）同「中学校学習指導要領」 1977, p.73 
3) 同「高等学校学習指導要領」 1978 , p. 47

4) 中村雄二郎「術語集」岩波書店, 1984, p.81f.

5 ) V. ターナー, 梶原景昭訳「象徵と社会」 紀伊國屋書店, 1981, p.209f.

6 ) Victor Turner "Passag, Margns, and Poverty ; Religious Symbols of Communitas” Ed. by J.C.Harrs \& R.J.Park, PLAY, GAMES \& SPORTS in Cultural Contexts, Human Kinetics Publishers Inc. 1983, pp. $327-59$

7 ）山口昌男「文化の詩学 I」岩波書店, 1983, pp. $317-55$

8）同「文化と両義性」岩波書店, 1982, 第 9 刷（第 1 刷 1975 年），pp. 229-44

9 ） E.リーチ 青木 保・宮坂敬造訳「文化 とコミュニケーション」紀伊國屋書店,

第 8 刷, （第 1 刷, 1981年) 1983年, pp.157 $-61$

10）青木 保「義礼の象徵性」岩波書店, 1984, p. $260 f$.

11）中村雄二郎 前出 4) p.126f.

12）同 同上 pp.113-15

13）市川浩 $「<$ 身>の構造」青土社, 1984, pp. $76-95$

14）荒井貞光 チーム・ワークを生み出すための 集団運営の技術 日本体育協会監修「コーチ のためのスポーツ人間学」大修館, 1981 , p. 270

15）不昧堂「新修体育大辞典」 1976 .

16）杉本厚夫 都市住民の生活意識とスポーツ

条野豊編著「スポーツ社会学講座 2 現代 社会とスポーツ」 不昧堂, 1984,p.290

17）中村雄二郎 前出 4) p. 1415

18）杉本厚夫 シンボルとしてのスポーツの意味 空間 (1) 一一文化記号論的アプローチ「 広島体育学研究第 10 号」広島体育学会 pp.21 $-32,1984$

19）阿部一佳「根性」の記号論一バドミントン の場合「体育の科学」Vol.34,No.2,pp.

103-06, 1984
20）新村出編「広辞苑」第三版, 岩波書店, 1983.

21）池上嘉彦「記号論への招待」岩波書店, 1984, p.117 